УДК 378.147

DOI:

Оксана Микитюк, доктор педагогічних наук, доиеет кафедри життєвих компетентностей КЗ ЛОР “Львівський обласний інститут післядипломної педагогічної освіти” Андрій Зачепа, доктор філософських наук, професор, завідувач кафедри суспільно-гуманітарних наук Української академії рукарства

\title{
АСПЕКТИ ФОРМУВАННЯ ЕКОЛОГІЧНОЇ КУЛЬТУРИ В КОНТЕКСТІ ЕКОЛОГООРІЕНТОВАНОЇ ДІЯЛЬНОСТІ ВЧИТЕЛЯ
}

У статті здійснено спробу визначити та схарактеризувати аспекти формування екологічноі культури в контексті екологоорієнтованої діяльності вчителя. 3'ясовано, щзо аспекти формування екологічної культури передбачають екологоорієнтовану діяльність вчителя системи післядипломної педагогічної освіти як педагогічну діяльність з використанням сучасних педагогічних технологій, що забезпечують перетворення комплексу екологічних знань, умінь, навичок, особистісних ставлень і ціннісних орієнтацій в регулятив екологоорієнтованої взаємодії.

Ключові слова: екологоорієнтована діяльність, екологічна культура, екосередовище "здорова школа - сприятливе екосередовище”, післядипломна педагогічна освіта.

Jim. 14.

Oksana Mykytyuk, Doctor of Sciences (Pedagogy), Associate Professor of the Vital Competencies Department Lviv Regional Institute of Postgraduate Pedagogical Education Andriy Zachepa, Doctor of Sciences (Philosophy), Professor, Head of Social and Humanitarian Sciences Department Ukrainian Academy of Printing

\section{THE ASPECTS OF FORMATION OF ENVIRONMENTAL CULTURE IN THE CONTEXT OF ECOLOGY-ORIENTED ACTIVITIES OFTEACHER}

The article attempts to identify and characterize the formation of aspects of ecological culture in the context of the teacher's environment-oriented activity. It finds out that the aspects of formation of ecological culture presuppose the ecologically oriented activity of the teacher in the system of postgraduate pedagogical education as pedagogical activity, using the modern pedagogical technologies that ensure the transformation of the complex which includes: the ecological knowledge, abilities, skills, personal attitudes and valuable orientations in the regulation of ecologically oriented interaction. The modern formation strategy of the ecological culture of a teacher is considered in the context of ecologically oriented activity and takes into account the aspects of the activity component. The formation of ecological culture in the context of ecologically oriented activity provides, as one of the options, the creation of a favorable eco-environment "healthy school - a favorable eco-environment" in the school classes, in the post-school educational area, and in the pre-school space.

Keywords: the ecologically oriented activity, ecological culture, the ecological environment "healthy school - favorable ecological environment", the postgraduate pedagogical education.

П остановка проблеми. Прагнення до гуманізації освіти в Україні $\epsilon$ характерною особливістю сучасної системи освіти і педагогічної зокрема. Тим не менше це $є$ одним з шляхів подолання негативних явищ у сфері професійної підготовки педагогів. Різні зміни соціального середовища, професійних вимог і технологічних можливостей людства ведуть до створення особливого типу взаємовідносин між суб'єктами навчальновиховного процесу, що в кінцевому результаті сприятиме максимальній реалізації потенційних можливостей особистості та допомагатиме їй у фізичному та духовному розвитку. У основі гуманістичної-орієнтованої освіти післядипломної педагогічної освіти знаходяться особливі стосунки: взаємодія, взаємна творчість, здатність реалізувати принципи гуманістичної психології - принципи розвитку, цілісності, гуманності, цільового детермінізму, активності, та принцип репрезентативності. Проте, незважаючи на значний інтерес науковців до післядипломної педагогічної освіти, ряд проблем професійного розвитку вчителів як у теоретичному, так і в практичному аспекті досі є малодослідженими, що виявляється у відсутності єдиного розуміння сутності процесів, теоретично визначених та методологічно обгрунтованих моделей, розроблених й експериментально апробованих технологій професійного розвитку вчителів системи післядипломної педагогічної освіти.

Разом $з$ тим, майже не вивчені особливості 


\section{АСПЕКТИ ФОРМУВАННЯ ЕКОЛОГІЧНОЇ КУЛЬТУРИ В КОНТЕКСТІ ЕКОЛОГООРІЄНТОВАНОЇ ДІЯЛЬНОСТІ ВЧИТЕЛЯ}

методології і теорії екологоорієнтованої діяльності у поєднанні 3 екологічним вихованням, формуванням екологічної культури у вчителя, генезис іiї основоположних принципів, функцій, ціннісно-цільових установок. Цікавим є напрям поєднання екологічного виховання, формування екологічної культури в руслі екологоорієнтованої діяльності вчителя $[2 ; 3 ; 4 ; 5 ; 8 ; 9 ; 10]$.

Професійна діяльність вчителя системи післядипломної педагогічної освіти, на думку О. Дубасенюк, є особливим видом соціальної діяльності, що спрямована на передавання новим поколінням накопичених людством досвіду і культури, створення умов для їх особистісного розвитку [6]. Також професійна діяльність вчителя - це процес, що розпочинається із засвоєння ним раніше накопиченого (адаптація, репродукція, відтворення знань), який потім переходить у перетворення власного досвіду. При цьому сутність динаміки професійного розвитку виявляється у зміні позиції вчителя від пристосування до педагогічної ситуації до іiі перетворення (С. Смирнов). Варто зазначити що, професійна діяльність вчителя спрямовується на подолання протиріччя між наявним рівнем фахової підготовки та рівнем професіоналізму, яким він повинен володіти (О. Сухомлинська) [13].

Низка учених (О. Колонькова, Н. Пустовіт, О. Пруцакова, Л. Руденко та інші) розрізняють два рівні екологічної освіти: базовий, призначений для широких верств населення, котрі в своїй професійній діяльності здійснюють несуттєвий вплив на стан довкілля, та поглиблений, характерний для професійних груп, діяльність яких створює суттєве навантаження на довкілля, чи тих, хто займається безпосередньо природоохоронною діяльністю [10]. До розгляду пропонуються два види екологічної компетентності - повсякденно-побутова, що виявляється у повсякденному житті, й професійна, яка характеризує людину як суб'єкта професійної діяльності, їі здатність успішно виконувати свої повноваження. Поряд із соціально-економічними перетвореннями суттєвою рисою сучасної цивілізації залишається стрімкий розвиток соціоекологічної кризи, що комплексно проявляється у вигляді різноманітних невирішених проблем у соціальній, демографічній, економічній та інших сферах, сферах освіти і науки і духовного розвитку людини.

Розглядаючи екологоорієнтовану діяльність як особливий вид педагогічної діяльності, в процесі якої цінності екологічної культури обумовлюють формування якісно нових екологоорієнтованих відносин, і відповідно ми бачимо екологоорієнтовану діяльність вчителя системи післядипломної педагогічної освіти як педагогічну діяльність $з$ використанням сучасних педагогічних технологій, що забезпечують перетворення комплексу екологічних знань, умінь, навичок, особистісних ставлень і ціннісних орієнтацій в регулятив екологоорієнтованої взаємодії.

Аналіз останніх досліджень і публікацій. Екологічна проблематика на сучасному етапі розвитку людства виявляється в постійно наростаючому загостренні протиріч у взаєминах суспільства і природи і залишається на сьогодні вкрай актуальною. При цьому вся складність і серйозність даної ситуації обумовлена не стільки погіршенням стану навколишнього довкілля, економічних ризиків, проблем у інших сферах суспільного життя, скільки кризовим станом самої людини, століттями сформованим споживацьким ставленням до навколишнього середовища $[1 ; 3 ; 4 ; 5]$.

На перший план виступає необхідність екологоорієнтованої освіти як особистості так і суспільства, переорієнтація світоглядулюдини на екологоорієнтований світогляд, і відповідно, впровадження принципу взаємодії людини 3 навколишнім середовищем на паритетних основах, що забезпечує формування стійкого розвитку в системі “Людина - Природа Суспільство”. Очевидно, що у зв’язку з цим провідну роль відіграє екологоорієнтована освіта вчителів в системі післядипломної освіти, оскільки найважливішим напрямом на сьогодні, як ми вважаємо, є налаштування вчителів до усвідомленої та екологічно-доцільної взаємодії. Збільшення кількості екологічно орієнтованих фахівців психологічно, теоретично і практично готових до реалізації ідей сталого розвитку природи і суспільства у своїй професійній діяльності, 3 відповідними соціальноекологічними ініціативами, фахівців 3 високим рівнем професійно-екологічної культури у системі післядипломної педагогічної освіти є зараз вкрай доцільне і необхідне.

У контексті наукового осмислення проблеми екологоорієнтованої діяльності вчителя значний науковий і практичний інтерес для нашого дослідження становлять праці С. Артановського, Г. Бачинського, А. Гагарина, М. Голубця, Л. Лук'янової, С. Совгіри та інших. $€$ велика кількість наукових досліджень щодо структури екологічної компетентності (А. Вітинська, Г. Гойдаш, Л. Лук'янова, О. Пруцакова, Н. Пустовіт, С. Шмалей), що розглядають структуру як здатність особистості до ситуативної діяльності в соціумі і природному оточенні, коли набуті 


\section{АСПЕКТИ ФОРМУВАННЯ ЕКОЛОГІЧНОӤ КУЛЬТУРИ В КОНТЕКСТІ ЕКОЛОГООРІЕНТОВАНОӤ ДІЯЛЬНОСТІ ВЧИТЕЛЯ}

екологічні знання, навички, досвід і цінності актуалізуються в умінні мислити і виконувати адекватні дії, усвідомлюючи їх наслідки для довкілля $[3 ; 9 ; 10]$.

Всі дослідники сходяться на думці, що в сучасних умовах глобалізації, інтеграції та інформаційного суспільства зростає роль системи післядипломної освіти, актуальними стають завдання професійного розвитку вчителів, зокрема в контексті екологоорієнтованої діяльності. Відповідно, якісно нового значення набуває діяльність закладу післядипломної педагогічної освіти щодо забезпечення науковометодичного супроводу професійного розвитку педагогічних працівників в умовах регіону. Сьогодні в Україні післядипломна педагогічна освіта здійснюється Університетом менеджменту освіти Національної академії педагогічних наук України; регіональними закладами післядипломної педагогічної освіти, підрозділами вищих навчальних закладів (філіалами, факультетами, відділеннями та ін.). За С. Крисюком у структурі сучасної системи післядипломної освіти педагогів можна виокремити такі п'ять елементів: підвищення кваліфікації, підготовку, перепідготовку, аспірантуру, докторантуру й самоосвіту [7].

Наукове осмислення вчителями екологоорієнтованого виховання учнів в руслі соціально-культурної діяльності, формування екологічної культури вчителя - не тільки перспективний шлях розкриття можливостей природно-культурної спадщини та національно-культурних цінностей в формуванні екологічної культури учнів, батьків, населення, а й важливий інструмент оптимізації соціальної взаємодії в вирішенні локальних і глобальних екологічних проблем.

В концепції Нової української школи, зокрема актуалізується, що “метою базової загальної середньої освіти є розвиток і соціалізація учнів, формування їхньої національної самосвідомості, загальної культури, світоглядних орієнтирів, екологічного стилю мислення і поведінки, творчих здібностей, дослідницьких і життєзабезпечувальних навичок, здатності до саморозвитку й самонавчання в умовах глобальних змін і викликів" [1]. Для формування ключових і предметних компетентностей у зміст кожного предмету закладено наскрізні змістові лінії: “Екологічна безпека та сталий розвиток”, “Громадянська відповідальність”, “Здоров’я і безпека", "Підприємливість і фінансова грамотність”.

Мета статті. Дослідження аспектів формування екологічної культури в контексті екологоорієнтованої діяльності вчителя системи післядипломної педагогічної освіти.
Виклад основного матеріалу дослідження. Проведений аналіз дозволив нам в своїй роботі представити екологоорієнтовану діяльність вчителя як цілеспрямований, вмотивований педагогічний процес формування і розвитку у учнів системної екологічної культури 3 перспективою створення у школі сприятливого екосередовища "здорова школа - сприятливе екосередовище”, тобто середовища, що дозволяє реалізувати педагогічні технології як інструмент формування та розвитку екологічних цінностей учнів у якісно нових суспільних відносинах. Тестування i анкетування вчителів за авторськими опитувальниками були проведені у КЗ ЛОР “Львівський обласний інститут післядипломної педагогічної освіти” впродовж 2015 - 2016 року. Проведене дослідження, у ході якого виявлено: низький рівень усвідомлення вчителями особливостей екологоорієнтованої діяльності та інноваційних форм екологоорієнтованої діяльності, відсугність належної мотивації вчителів до екологоорієнтованого професійного розвитку, низький рівень організації самоосвітньої діяльності, наявність бажання попри відсутність належної інформації до створення екосередовища “здорова школа - сприятливе екосередовище”.

Теоретичним підгрунтям для нашого дослідження є поняття “система”, “педагогічний процес”. Так, у педагогічній науці поняття “система" вміщено у терміні “педагогічна система". У педагогічному словнику: “педагогічна система" визначається так:

1) впорядкована кількість взаємопов'язаних компонентів, котрі утворюють єдине ціле і підпорядковані цілі навчання й виховання;

2) соціально-зумовлена цілісність учасників педагогічного процесу з їх матеріальними й духовними цінностями, які взаємодіють на основі співробітництва між собою та 3 навколишнім середовищем, спрямована на формування i розвиток особистості.

Відповідно, структура складається $з$ таких компонентів: учнів (кого вчити); мети навчання (з якою метою навчати); змісту навчання (чому навчати); дидактичних процесів; учителів (чи технічних засобів навчання); організаційних форм навчання. Оскільки педагогічна система передбачає взаємодію різних взаємопов' язаних структурних компонентів, спільною метою яких $\epsilon$ розвиток особистості, то педагогічний процес $\epsilon$ сукупністю організованої взаємодії педагогів та учнів (суб'єкт-суб'єктна взаємодія), узгодженням змісту освіти та використанням засобів навчання і виховання, які спрямовані на задоволення потреб суспільства й особистості. 


\section{АСПЕКТИ ФОРМУВАННЯ ЕКОЛОГІЧНОЇ КУЛЬТУРИ В КОНТЕКСТІ ЕКОЛОГООРІЄНТОВАНОЇ ДІЯЛЬНОСТІ ВЧИТЕЛЯ}

Отже, педагогічний процес - це своєрідне втілення зв'язків, взаємин між людьми, які виконують спільні завдання, взаємно впливають один на одного, доповнюють один одного й досягають успіхув реалізації поставлених завдань.

Структура педагогічного процесу є сталою: вона властива як педагогічному процесу загалом, що здійснюється в межах педагогічної системи, так і одиничному (локальному) процесу педагогічної взаємодії. Педагогічний процес визначає, встановлює, формує цілісну систему педагогічних взаємин учителів і учнів та сприяє розвитку суб'єктів цього процесу. Педагогічний процес організовується під час інтеграції основних компонентів навчання і виховання (мета, завдання, засоби, способи, форми взаємодії суб' єктів педагогічного процесу, їх діяльність, управління) у цілісну систему. Щодо професійних функцій вчителя, то вони в першу чергу зумовлені метою й завданнями освіти, особливостями навчально-виховного процесу та віковими особливостями учнів. Поняття “функція”: у педагогіці тлумачать як якісну характеристику, спрямовану на збереження, підтримку й розвиток системи освіти; призначення (роль) педагога (за О. Онопрієнком) [11, 40].

Дослідження видів професійної діяльності вчителя та відповідних їм функцій достатньо широко представлені у психолого-педагогічній літературі. Зокрема, А. Вербицький функції вчителя розуміє як його певні ролі у навчальновиховному процесі. Тому він виокремлює такі функціональні ролі вчителя, як предметник, методист, психолог, менеджер, вихователь [10]. На думку О. Дубасенюк [6], мета та зміст навчально-виховного процесуу загальноосвітньому навчальному закладі зумовлюють такі функції професійної діяльності вчителя, як інформативна, розвивальна, виховна, орієнтувальна, культурологічна, мобілізаційна, стимулювальна, конструктивна, комунікативна, організаційна, соціалізуюча, управлінська, діагностична, дослідницька, прогностична, психотерапевтична, рекреаційна (екологоорієнтована), здоров'язбережувальна, коригуюча, методична.

Завдяки конкретизації 3 точки зору екологоорієнтованої діяльності екологічна культура, екологічна діяльність, екологічні цінності, екологоорієнтоване середовище, екосередовище “здорова школа - сприятливе екосередовище” набувають особливого сенсу, предметності і конкретизації. Екологічна культура являє собою компонент екологічної культури суспільства в цілому і передбачає оцінювання засобів, якими здійснюється безпосередній вплив людини на природне середовище, а також засобів духовно-практичного освоєння природи (відповідні знання, культурні традиції, ціннісні установки і т.д.).

Екологічний підхід призвів до утворення всередині педагогіки такого поняття, як “екологія культури", в рамках якої осмислюються шляхи збереження та відновлення різних елементів культурного середовища, створеної людством на протязі його історії [10]. Зазвичай виділяють дві сторони в системі екологічної культури: духовну (екологічні знання, переконання, цінності) i матеріальну (всі форми діяльнісної взаємодії суспільства 3 природою і результати цієї взаємодії).

У руслі нашого розуміння екологічного виховання учнів як екологоорієнтованої діяльності ми виділяємо основні структурні елементи соціально-екологічної форми діяльності, які складаються в штучному середовищі існування людини і опосередковано впливають на природне середовище; соціально-екологічні цінності, які включають, по-перше, відносини людини безпосередньо до природнього середовища існування, по-друге, відносини в матеріальновиробничих сферах людської життєдіяльності, пов'язаних 3 процесом привласнення людиною природних сил, енергії і речовини; і по-третє, відношення людини до природніх умов існування, закріплених в етноекологічних традиціях природокористування. Розглянемо структурні елементи більш докладно.

Поняттям екологічна діяльність в найбільш узагальненому вигляді розглядаються в певному аспекті різні види людської діяльності в матеріально-практичній та теоретичній сферах, в тій чи іншій ступені відносяться до вивчення, освоєння, перетворення і збереження природного середовища.

Таким чином, це, з одного боку, найбільш обширна область людської діяльності, а $з$ іншого - область, яка лежить в основі вихідного, первинного життєзабезпечення людини. Мабуть, людина займався екологічною діяльністю з самого свого виникнення на Землі. Ця діяльність послідовно видозмінювалася в відповідності 3 різними етапами розвитку екологічної культури, і на сьогодні відповідає новому типу екологічної культури. У практичному плані екологічна діяльність - це виробнича діяльність людини з перетворювальними і природоохоронними цілями, тобто сфера природокористування. В ідеалі раціональне природокористування має слідувати принципам нового екологічного мислення, постулатам сталогорозвитку, найсучаснішим науковим розробкам, природоохоронним 


\section{АСПЕКТИ ФОРМУВАННЯ ЕКОЛОГІЧНОӤ КУЛЬТУРИ В КОНТЕКСТІ ЕКОЛОГООРІЄНТОВАНОӤ ДІЯЛЬНОСТІ ВЧИТЕЛЯ}

юридичним нормам i, грунтуючись на них, грамотно впливати на виробничу діяльність людини, передбачаючи можливі негативні наслідки. 3 захисними нормами екологічної діяльності тісно пов'язані більш загальні правила екологічної поведінки, які згідно з новим типом екологічної культури і постулатам сталого розвитку повинні пунктуально відповідати гуманістичній етиці.

Все більшого значення останнім часом в області екологічної культури набуває проблематика розробки її теоретичних основ. Ще одним важливим аспектом, що входять в коло екологічної культури особистості, $є$ проблема змісту процесу виховання екологічної культури особистості. Особливо гостро це питання торкається учнів (екологічна культура учнів), i вчителів (система післядипломної педагогічної освіти).

Нарешті, екологічна культура особистості немислима поза іiі діяльнісно-практичним відношення до дійсності, основу якої повинні складати цінності екологічної культури. В процесі освоєння простору екологічної культури вчитель усвідомлює систему екологічних норм і цінностей, поступово адаптуючись до екологоорієнтованої поведінки у середовищі. Діяльнісний компонент формування екологічної культури вчителя в контексті екологоорієнтованої діяльності враховує такі аспекти:

- аспект мотиваційної діяльності, перетворення екологічних цінностей в екологічні прагнення;

- аспект екологоорієнтованості, що проявляється в ціннісно-орієнтованій діяльності. Проектуючи даний аспект, можна виділити основні детермінанти цінностей екологічного виховання: 1) мотиваційно-комунікативний, який передбачає формування комплексного (емоційного i раціонального); 2) формування емоційноособистісного ставлення до навколишнього природного середовища через екологоорієнтований підхід;

- аспект інформаційно-когнітивний, що передбачає дії від запам’ятовування і відтворення алгоритму екологоорієнтованої поведінки від теорії до застосування на практиці;

- аспект діяльнісний, що передбачає оволодіння екологоорієнтованими технологіями взаємодії в контексті створення сприятливого екосередовища “здорова школа - сприятливе екосередовище”. Екосередовище “здорова школа - сприятливе екосередовище" - це середовище формування і реалізації соціоекологічних особистісних ставлень і ціннісних орієнтацій учителя, яке створене 3 лікарських рослин на пришкільній навчально-дослідній ділянці, у класі, пришкільному просторі [10].

Висновок. Сучасна стратегія формування екологічної культури вчителя розглядається нами у руслі екологоорієнтованої діяльності і враховує аспекти діяльнісного компоненту. Дослідження у даному розрізі варто продовжувати, оскільки $\epsilon$ потреба розробки методологічних принципів, змісту, форм і методів розвитку екологічної культури вчителя в системі післядипломної педагогічної освіти, вирішення проблем створення екосередовища “здорова школа - сприятливе екосередовище”.

\section{ЛІТЕРАТУРА}

1. Концепція Нової української школи https:// osvita.ua/school/reform/54276/ (2017)

2. Артановский С. Н. Охрана окружающей среды и культурно-просветительная деятельность: учебное пособие. - Л., 1988.

3. Бачинський Г. О. Основи соціоекології / Г. О. Бачинський, Н. В. Бренда, В. Д. Бондаренко та інш; за ред. Г.О. Бачинського // К.: Вища школа. 1995. - 238 c.

4. Гагарин А.В. Природоориентированная деятельность учащихся как условие формирования экологического сознания: дис. ... д-ра пед.наук. - Москва, 2004.-346с.

5. Голубець М. А. Від біосфери до соціосфери / М. А. Голубець. - Львів, 1997. - 256 с.

6. Дубасенюк О. Професійна педагогічна діяльність: сутність та сучасні підходи / О. Дубасенюк // Професійна підготовка педагогічних працівників. - Житомир, 2000. - 270 с.

7. Крисюк С. В. Розвиток післядипломної освіти педагогічних кадрів в Україні /С.В. Крисюк. - Львів, 1997. - 256 с.

8. Лихачев Б.Т. Экологическая культура личности // Философия воспитания. - М.: Прометей. 1985. - 170 с.

9. Лук'янова Л. Б. Екологічна компетентність майбугніх фахівців: навч.-мет. посібник/Л.Б. Лук'янова, О.В. Гуренкова. - Ін. пед. освіти дорослих АПН України. К.: Ніжин., ПП. Лисенко, 2008. - 243 с.

10. Микитюк О.М. Компетентнісний підхід до забезпечення здорового способу життя у сприятливому екосередовищі./ О. М. Микитюк, О. I. Шиян // (Гриф МОН №1.4/18-1845 від 25.05.2009 р.). Львів: ЦПД, 2009, - 136 с.

11. Онопрієнко О. В. Інтегративні характеристики базових професійних компетентностей учителя / О.В. Онопрієнко // Вісник Черкаського університету. - 2007. - Вип. 113. - С. 38-44.

12. Ситаров, В.А. Социальная экология / В.А. Ситаров, В.В. Пустовойтов. - М., 2000. - 200 с.

13.Сухомлинська О. В. Концепція громадянської 


\section{АСПЕКТИ ФОРМУВАННЯ ЕКОЛОГІЧНОЇ КУЛЬТУРИ \\ В КОНТЕКСТІ ЕКОЛОГООРІЄНТОВАНОЇ ДІЯЛЬНОСТІ ВЧИТЕЛЯ}

освіти в школах України / О. В. Сухомлинська // Шлях освіти. - 2001. - № 1. - С. 26-31.

14. Gusfield, L. Nature in ecological education. From knowledge to love. - New York: Harcout, 1998.

\section{REFERENCES}

1. Konsepsia Novoi Uktainskoi shkolu (2017). [A concept of the New Ukrainian School]. Available at: https://osvita.ua/school/reform/54276/ [in Ukrainian].

2.Artanovskiy, S.N. (1988). Ochrana okryzhaychey sredy u kylturno-prosvetitelskaj [Collection of scientific works]. [in Russian].

3. Bachinski, G O. (1995). Osnovu sociolecologii [Basis of socioecology]. High school.Kyiv, 238 p. [in Ukrainian].

4. Gagarin, A.V.(2004). Prirodoorientirovannaj dejtelnost ychachihsa kak yslovie formirovanie ekologicheskogo soznania [The nature-oriented activity of students as a condition for the formation of ecological consciousness]. Doctor's thesis. Moskow, 346p.[in Russian].

5. Golubers, M.A. (1997). Vid biosfery do cosiosferu [From the biosphere to the cosmos]. Lviv, 256 p. [in Ukrainian].

6. Dybasenyk, O. (2000). Profesijna pedagogichna dialnist sytnist ta sychasni pidchody [Professional pedagogical activity: essence and modern approaches]. Profesiina pidhotovka pedahohichnykh pratsivnykiv. Zhytomyr, $270 \mathrm{p}$. [in Ukrainian].

7. Krusyk, S.V. (1997). Rozvytok pisladiplomnoi osvity pedagogichnich kadriv na Ukraini
[Development of postgraduate education of teaching staff in Ukraine]. Lviv, 256 p. [in Ukrainian].

8. Lichachev, B.T. (1985). Ecologicheskaj kyltyra lichnosti [Ecologicalculture ofthe person].Journal Philosophy of upbringing. Moskow: Prometheus, 170 p. [in Russian].

9. Lukianova, L.B. \& Hurenkova, O.V. (2008). Ekologichna competentnist majbytnich fachivzciw [Ecological competence of future specialists]. Tutorial manual Institute for Adult Pedagogical Education. Kyiv, Nizhyn, 243 p. [in Ukrainian].

10. Mykytyuk, O.M. \& Shyian, O. I. (2009). Kompetentnisniy pidchid do zabezpechenna zdorovogo sposoby zutta y spriatlivomy seredovichi [Competency approach to providing a healthy lifestyle in a supportive environment]. The manual with the stamp MES №1.4/18-1845 від 25.05.2009 p.). Lviw: ZPD, 136 p. [in Ukrainian].

11. Onoprienko, O.V. (2007). Integrativni characteristiky bazovych profesiynych kompetentnostey [Integrative characteristics of the basic professional competences of the teacher]. Bulletin of Cherkasy University. Vol. 113, pp. 38-44. [in Ukrainian].

12. Sitarow, V.A. \& Pustovoytov, V.V. (2000). Socialnaja ekologia [Socioecology]. Moskow, 200 p. [in Russian].

13. Sychomlinska, O.V. (2001). Kontseptsiia hromadianskoi osvity $v$ shkolakh Ukrainy [Concept of civic education in schools of Ukraine]. Shliakh osvity, no. 1, pp. 26-31. [in Ukrainian].

14. Gusfield, L. (1998). Nature in ecological education. From knowledge to love. New York: Harcout. [in English].

Стаття надійшла до редакції 14.02.2018

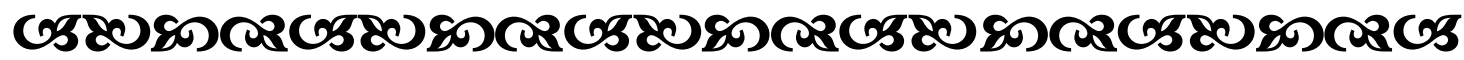

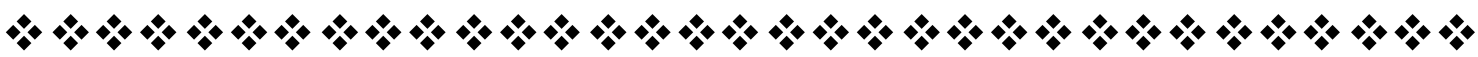 9 березня-Dень народження ТТараса Шевиенка}

Теній. Лрометей. Кобзар.

Надзвичайно талановитий уқраӥнський поет і художник, прозаїк $і$ етнограбб. Ақадемік.

Він народився у рабській родині, ще маленьким став қруглим сиротою $і$ ріс $у$ цілқовитій бідності й тотальній безвиході. ТТа все Ж знайшов шлях з тунелю қріпаџтва, став відомим на весь світ, створював нев'янучі світові шедеври в різних жанрах.

Із 47 років його земного буття 24 роқи-рабство, 10 роқів-солдатсьқа служба в Мангишлаку, а лічені роқи відносно споқійного життя - ие роқи боротьби і просвіти, пошуку правди і творення вічного в мистещтві.

\section{$\% * \% * \% * \% * \%$ C28080 GS(28)}

